\title{
Characterization of a vaccinia virus strain used to produce smallpox vaccine in Argentina between 1937 and 1970
}

\author{
Brief Report \\ A. Lewis ${ }^{1}$, K. Bok ${ }^{1}$, O. Perez ${ }^{2}$, J. DeFillippo ${ }^{2}$, C. Paolazzi ${ }^{2}$, and J. A. Gomez ${ }^{1}$ \\ ${ }^{1}$ Virology Department, National Institute of Infectious Diseases, Buenos Aires, \\ Argentina, ANLIS, Buenos Aires, Argentina \\ ${ }^{2}$ National Institute of Biological Production, ANLIS, Buenos Aires, Argentina
}

Summary. Due to recent political developments, smallpox has re-emerged as a serious threat. We recovered and characterized an old batch of smallpox vaccine, Malbrán strain, produced between 1945 and 1949. The virus was re-isolated and characterized by sequence analysis and biological activity in animals. Phylogenetic analysis using the hemagglutinin and A45R genes showed that the Malbrán strain was closely related to the Lister strain of vaccinia virus. In animals, the Malbrán strain exhibited low pathogenicity, confirming historical records. Mice immunized with the Malbrán strain survived a lethal challenge with cowpox virus. Thus, this strain of vaccinia virus remains a viable candidate as a smallpox vaccine.

\section{*}

Through the implementation of a global immunization campaign, smallpox disease was eradicated worldwide in 1980. The Dr. Carlos G. Malbrán National Institute of Microbiology was the smallpox vaccine producer in Argentina from 1937 until production stopped in 1980. The documented history of the vaccine produced by the institute and used in Argentina, the Malbrán strain, is traceable to a strain obtained from Argentina's Smallpox Vaccine Conservatory of the National Department of Hygiene in 1937 [16]. Unfortunately, the Malbrán strain's original source is unknown since records before 1928 are unavailable [16]. The Malbrán strain was used in vaccination programs in Argentina until 1970 after which time the Lister strain was adopted following WHO recommendations [6] until vaccination ceased in 1980. 
Recent worldwide political developments and reports on potential bioterrorist attacks $[8,13]$ suddenly have made smallpox a serious re-emerging disease threat against which vaccines are needed. Historical records indicate that the Malbrán strain had an excellent record of efficacy with a low incidence of adverse effects in humans $[3,14]$. We therefore resurrected virus from an old batch of glycerinated Malbrán smallpox vaccine, produced between 1945 and 1949 and stored in a $-20{ }^{\circ} \mathrm{C}$ freezer, for characterization.

Ten percent dilutions of the glycerinated vaccine in Eagle's Minimum Essential Medium supplemented with 2\% fetal bovine serum were adsorbed on RK-13 and PTP (human foreskin fibroblasts) cells. When the extent of cytopathic effect was greater than $90 \%$, the infected cells were frozen and thawed twice to produce viral stocks which were aliquoted and stored at $-80^{\circ} \mathrm{C}$. The vaccine titer was determined by seeding ten-fold dilutions of vaccine on chorioallantoic membranes (CAMs) of 11-day-old embryonated eggs as previously described [7]. Titers produced in RK-13 and PTP cells ranged from $10^{7}$ to $10^{8} \mathrm{PFU} / \mathrm{ml}$. Inoculated CAMs incubated 3 days at $36^{\circ} \mathrm{C}$ showed $4-6 \mathrm{~mm}$ white pocks, a few of which were slightly hemorrhagic. The titer obtained in CAM's was $1 \times 10^{3} \mathrm{PFU} / \mathrm{ml}$. The ceiling temperature, defined as the maximum temperature at which formation of pocks occurred following inoculation of CAM's with $10^{2} \mathrm{PFU}$ of virus and three days incubation [5, 6], was found to be $41^{\circ} \mathrm{C}$. Transmission electron microscopy of infected PTP cells [MOI $=1 \mathrm{PFU} /$ cell, fixed at 40 hours post infection at $37^{\circ} \mathrm{C}$ as described previously [11] revealed that of 2176 virions counted in twenty randomly selected thin sections [1, 9, 12], $1672(77 \%)$ were intracellular mature virions (IMV's), 124 (6\%) were intracellular enveloped virions (IEV's), and 349 (16\%) were cell-associated enveloped virions (CEV's); 31 (1\%) budding IMV were also counted.

The hemagglutinin (HA) coding gene of the Malbrán strain was amplified by PCR using primers for the Eurasiatic-African group of Orthopoxvirus, EACP 1 and EACP 2 and with G-VRB and G-EMVRB as previously described [15, 18]. Digestion of the $950 \mathrm{bp}$ amplified fragment with TaqI produced four bands of sizes expected from similar analysis of other vaccinia virus strains $(451,295,105$ and $97 \mathrm{bp}$; the HA of the MVA strain, included as a control, yielded the same bands). The HA fragment was purified (Wizard PCR Preps, Promega, Madison, WI) and sequenced (ABI PRISM Big Dye Terminator Cycle Sequencing Ready Reaction Kit, Perkin Elmer, Applied Biosystems, Foster City, CA) and part of the sequence, along with those of other strains, are shown in Fig. 1. For the Malbrán strain, the lowest nucleotide distance value and the maximum identity of the deduced amino-acid sequence was with the Lister strain ( $0.32 \%$ and $98.1 \%$ respectively). The Malbrán strain shares a $15 \mathrm{nt}$ deletion with the Lister and Lenny strains, but has a three nt deletion not found in the Lister strain. Phylogenetic analysis of the HA genes of several vaccinia virus strains and other Orthopoxviruses (Fig. 2A) showed that the Malbrán strain clustered with Lister, IOC, Lenny and Ankara strains, most of which derived from strains used for vaccine production in Europe $[5,17,18]$. The copper-zinc superoxide dismutase-like protein coding gene (A45R) was also amplified by PCR using primers 5' CCACCAGTAACCGCGTAC 


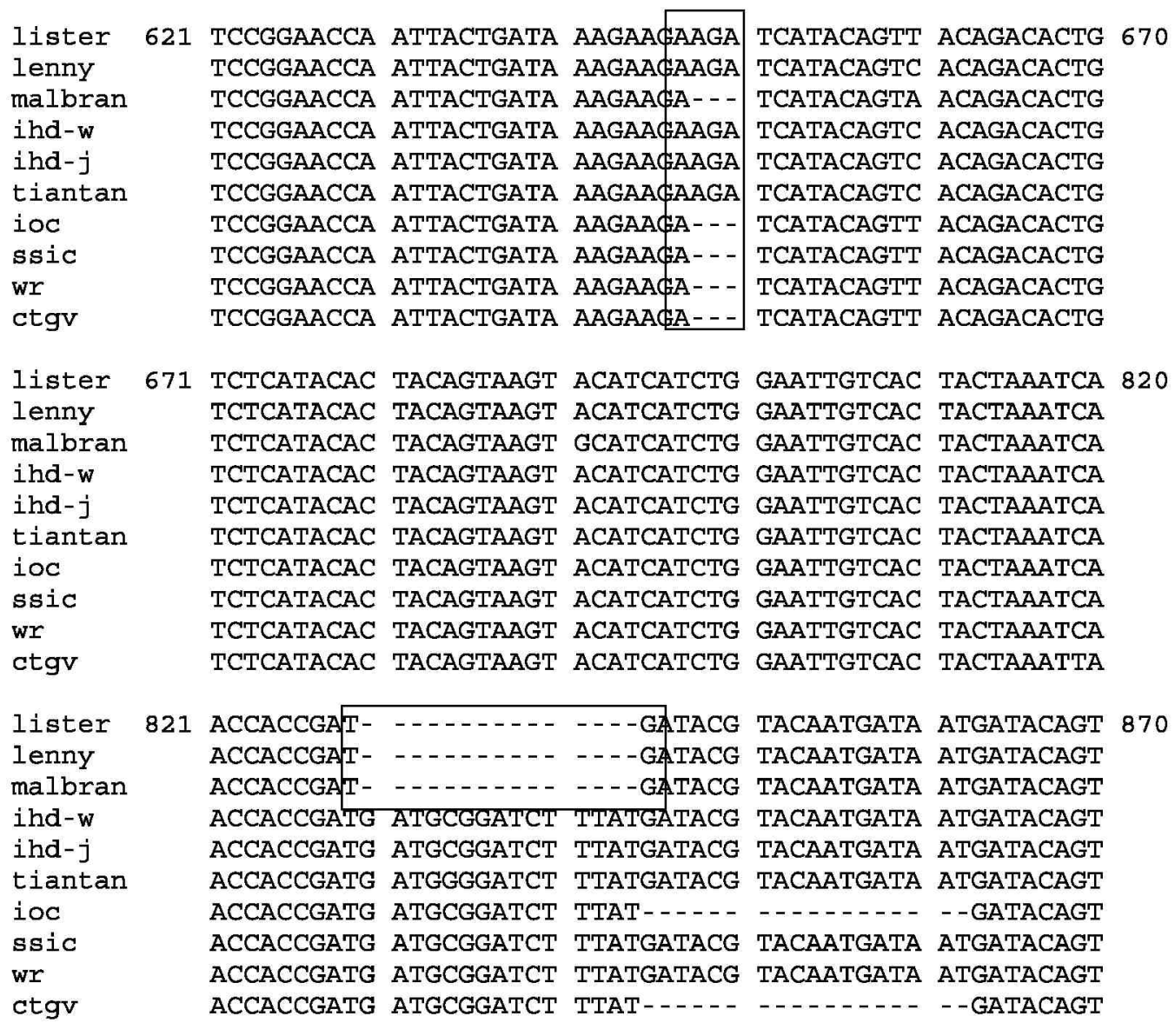

Fig. 1. Nucleotide sequence alignment of the viral hemagglutinin coding gene of Lister, Lenny, Malbrán, IHD-W, IHD-J, Tiantan, IOC, SSIC, WR, and CTGV strains showed a similar 15-nucleotide deletion (positions 730-744) among Malbrán, Lister and Lenny strains. In contrast, Malbrán and Lister strains differed in a deleted codon at positions 649-651, which is missing in the Malbrán strain, as well as in IOC, WR, CTGV and SSIC strains

$3^{\prime}$ and $5^{\prime}$ CCCTATCAAATTCGACAG $3^{\prime}$ partially designed based on published data [2]. This gene showed 100\% homology between the Malbrán, Lister and USSR strains (Fig. 2B). Overall, these results indicate that the Malbrán strain was derived from Lister or a Lister-related strain.

The pathogenicity of the Malbrán strain was assessed in rabbit [5,6] and mouse models $[10,19,20]$; the results are summarized in Table 1 . Rabbits were inoculated intradermal and mice were inoculated intracerebrally (IC), intranasally (IN), and intradermally (ID), all with $1 \times 10^{6} \mathrm{PFU}$ of Malbrán strain or the Brighton Red strain of cowpox virus (CPXV-BR) and then observed through 21 days for deaths and lesion size [19,20]. While none of the inoculated rabbits died, the Malbrán strain produced smaller lesions than did CPXV-BR). None of the mice inoculated IN or ID and only $1 / 10$ of the mice inoculated IC with the Malbrán strain died; in comparison, all of the mice inoculated IN and IC and 2/4 of the mice inoculated ID 
A

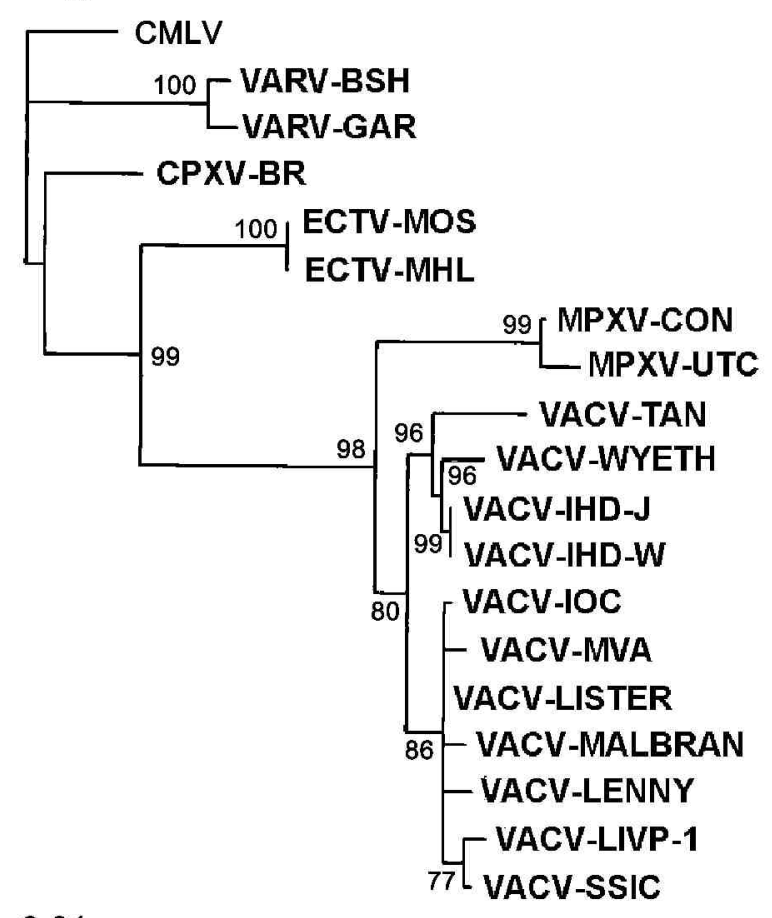

B

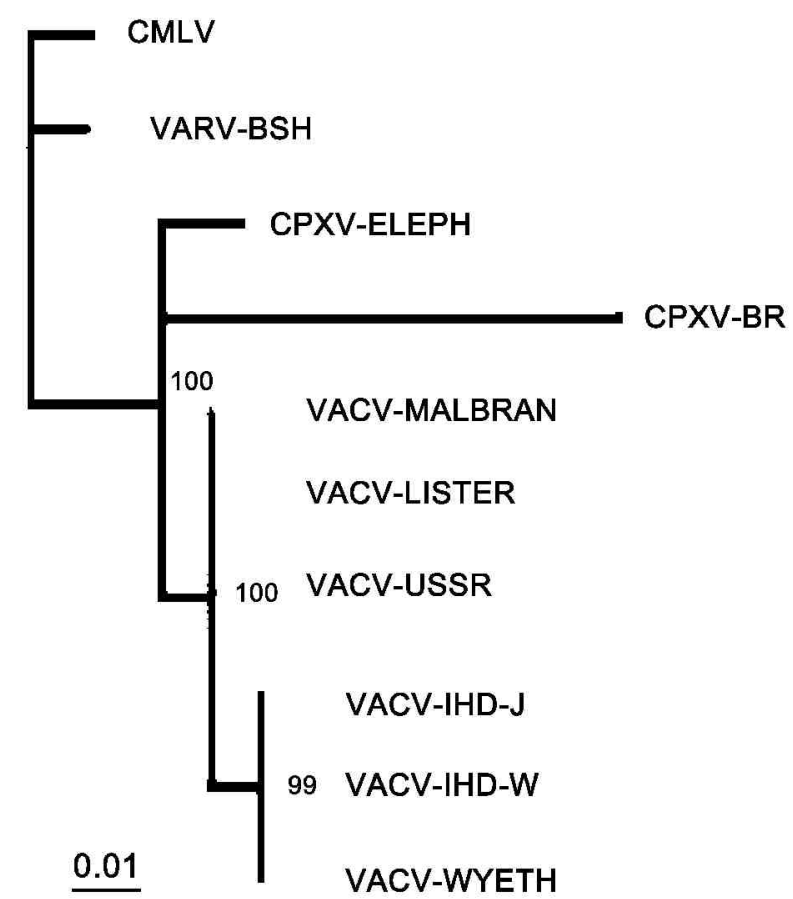

Fig. 2. A Phylogenetic analysis of viral hemagglutinin gene from selected VACV strains and old world Orthopoxviruses strains. CMLV: Camelpox (NC003391); VARV-Bsh: Variola Major strain Bangladesh (AF375140); VARV-Gar: Variola Minor strain Garcia (X72086); CPXV-BR: Cowpox strain Brighton Red (AF375087); ECTV-Mos: Ectromelia strain Mos (AF375092); ECTV-Mhl: Ectromelia strain Mhl (AF375091); MPXV-CON: Monkeypox strain Congo (AF375104); MPXV-UTC: Monkeypox strain Utrecht (AF375113); VACVIOC: Vaccinia strain Instituto Oswaldo Cruz (AF 229248); VACV-SSIC: Vaccinia strain Statens Serum Institut Copenhagen; VACV Malbrán (AY146624); VACV Ankara (U94848); VACV Tian-Tan (X15709); VACV IHD-J (M14783); VACV LIV-P1(Z99046); VACV Wyeth (Z99051). Sequences of Lister, IHD-W, Lenny and SSIC strains were kindly provided by Dr. Joseph Esposito and Dr. Susan Ropp from the Centers for Disease Control and Prevention, Atlanta, GA, USA. B Phylogenetic analysis of A45R gene sequences: VACV Malbrán (AY491665); CPXV Elephantpox (AF349016); CPXV Brighton Red (AF349015); VACV USSR (AF349008); VACV Lister (AF349007); VACV IHD-W (AF349005); VACV IHD-J (AF349004); VACV Wyeth (AF349003). Raw sequence data of the Malbrán strain were analyzed by the CHROMAS software (version 1.3, Mc Carthy 1996, Griffith University, Queensland, Australia). DNA sequences were aligned using Clustal X program. HA. Phylogenetic analysis was performed with Puzzle 4.02 program. Hasegawa distance model, neighbor joining input tree, 50,000 puzzling steps and uniform rate heterogeneity model were the parameters selected to obtain the maximum likelihood tree

with CPXV-BR succumbed. Lesions in the ear pinnae were also tenfold smaller following ID inoculation with Malbrán vaccinia virus vs CPXV-BR. These results attest to the low pathogenicity of the Malbrán strain. Finally, the ability 
Table 1. Pathogenicity of Malbrán strain in animal models

\begin{tabular}{lllll}
\hline Animals & $\begin{array}{l}\text { Inoculation } \\
\text { route }\end{array}$ & $\begin{array}{l}\text { Malbrán strain } \\
\text { deaths/total }\end{array}$ & $\begin{array}{l}\text { CPXV-BR } \\
\text { deaths/total }\end{array}$ & $\begin{array}{l}\text { Placebo } \\
\text { deaths/total }\end{array}$ \\
\hline Rabbits & ID & $0 / 3(9 \mathrm{~mm})$ & $0 / 2(14 \mathrm{~mm})$ & $0 / 2$ \\
Mice (Balb-C) & ID (Ear pinnae) & $0 / 4(1.2 \mathrm{~mm})$ & $2 / 4(>12 \mathrm{~mm})$ & $0 / 4$ \\
Mice(Balb-C) & IN & $0 / 15$ & $5 / 5$ & $0 / 5$ \\
Mice (NIH) & IC & $1 / 10$ & $5 / 5$ & $0 / 5$
\end{tabular}

Three rabbits were shaved and inoculated intradermically with $1 \times 10^{6} \mathrm{PFU}$ of Malbrán strain and examined daily for the appearance of lesions. Two rabbits were inoculated with similar titers of cowpox virus (Brighton Red strain) as a virulent control. Ten 18-21 g NIH mice were inoculated intracerebrally and fifteen 4 -week-old BALB/c mice were inoculated intranasally with $1 \times 10^{6} \mathrm{PFU}$ of Malbrán strain, respectively. Deaths were recorded during 21 days. The intradermal model was also used by inoculating four BALB/c mice in the ear pinnae with $1 \times 10^{6} \mathrm{PFU}$ of Malbrán strain. Lesion diameter was measured daily for 21 days

$I D$ : Intra-dermic; $I C$ : Intra-cerebral; $I N$ : Intra-nasal. Average lesion diameter showed in brackets

of the Malbrán strain to protect BALB/c mice against cowpox respiratory lethal infection was assessed. Two groups of ten 21 -day old BALB/c mice were vaccinated by tail scarification with $1 \times 10^{6} \mathrm{PFU}$ of Malbrán strain or with a placebo. Eight days after vaccination, the mice were challenged intranasally with a lethal doses $\left(2 \times 10^{6} \mathrm{PFU}\right)$ of CPXV-BR. All of the mice vaccinated with the Malbrán strain survived more than 21 days after the intranasal challenge with CPXV-BR and showed no signs of illness or weight loss. All mice vaccinated with the placebo became seriously ill and died between 6 and 9 days after the challenge with CPXV-BR.

In summary, characterization of the Malbrán strain of vaccinia virus indicate that it was originally derived from the Lister strain or a closely associated strain. Animal tests confirm the historical records of the moderated pathogenicity of the Malbrán strain [3, 14], who was able to protect mice against a lethal challenge with virulent cowpox virus. The Malbrán strain was used effectively in Argentina and other countries and its recovery after more than forty years may provide a useful tool against the emergence or reemergence of diseases produced by Orthopoxviruses.

\section{Acknowledgments}

The authors wish to thank Agustin Chertkoff for the assistance during the electron microscopy procedures, and Dr. Joseph Esposito for his helpful advice in the phylogenetic analysis. Cowpox virus, Brighton Red strain, was kindly provided by Dr. Erna Kroon. We are also grateful to Marcela Amoroso (D.V.M.) for her assistance with animal experiments, and to the Cell Culture Facility of the ANLIS-MALBRAN. 


\section{References}

1. Alain R, Berthiaume L (1993) Electron Microscopy. In: Payment P, Trudel M (eds) Methods and Techniques in Virology. Marcel Dekker, New York: 105

2. Almazán F, Tscharke DC, Smith GL (2001) The vaccinia virus superoxide dismutase-like protein (A45R) is a virion component that is nonessential for virus replication. J Virol 75(15): 7018-7029

3. Bray M, Martinez M, Smee D, Kefauver D, Thompson E, Huggins J (2000) Cidofovir protects mice against lethal aerosol or intranasal cowpox virus challenge. J Infect Dis 181: $10-19$

4. Damaso CR, Esposito JJ, Condit RC, Moussatche N (2000) An emergent poxvirus from humans and cattle in Rio de Janeiro State: Cantagalo virus may derive from Brazilians mallpox vaccine. Virology 277: 439-449

5. Esposito J, Fenner F (2002) Orthopoxvirus infections in humans. In: Knipe DM, Howley PM, Griffin DE, Lamb RA, Martin MA, Roizman B (eds) Fields virology. 4 edn, vol 2. Lippincott, Williams and Wilkins, Philadelphia

6. Fenner F, Henderson DA, Arita I, Jezek Z, Ladny ID (1988) Smallpox and its eradication. World Health Organization, Geneva

7. Gebhard W, Anderson H (1957) Procedimiento para la manufactura de vacuna antivariólica glicerinada, utilizado por la Division de Laboratorios del Departamento de Sanidad de Michigan. Boletin de la Oficina Sanitaria Panamericana 42: 100-125

8. Henderson DA, Inglesby TV, Bartlett JG et al. (1999) Smallpox as a biological weapon: medical and public health management. Working Group on Civilian Biodefense. JAMA 281: 2127-2137

9. Law M, Hollinshead R, Smith GL (2002) Antibody-sensitive and antibody-resistant cellto-cell spread by vaccinia virus: role of the A33R protein in antibody-resistant spread. J Gen Virol 83: 209-222

10. Marennikova S (1972) Evaluation of vaccine strains by their behaviour in vaccinated animals and possible implications of the revealed features for smallpox vaccination practice. In: International Symposium on Smallpox Vaccine. Bilthoven, Netherlands

11. Martinez M, Bray M, Huggins J (2000) A mouse model of aerosol-transmitted orthopoxviral disease. Arch Pathol Lab Med 124: 362-377

12. Meiser A, Boulanger D, Sutter G, Krijnse Locker J (2003) Comparison of virus production in chicken embryo fibroblasts infected with the WR, IHD-J and MVA strains of vaccinia virus: IHD-J is the most efficient in trans golgi network wrapping and extracellular enveloped virus release. J Gen Virol 84: 1383-1392

13. Meltzer MI, Damon I, LeDuc JW, Millar JD (2001) Modeling potential responses to smallpox as a bioterrorist weapon. Emerg Infect Dis 7: 959-969

14. Pirosky I (1961) La vacuna antivariólica del Instituto Nacional de Microbiología. Acta Krausi 2: 43-52

15. Ropp SL, Jin Q, Knight JC, Massung RF, Esposito JJ (1995) PCR strategy for identification and differentiation of smallpox and other orthopoxviruses. J Clin Microbiol 33: 2069-2076

16. Sordelli A, Biglieri R, Harispe C (1940) La vacuna antivariolica. Revista del Instituto Bacteriologico del Departamento Nacional de Higiene 9: 454-470

17. Strimmer K, von Haeseler A (1996) Quartet Puzzling: A quartet maximum-likelihood method for reconstructing tree topologies. Mol Biol Evol 13: 964-969

18. Trindade GS, da Fonseca FG, Marques JT, Nogueira ML, Mendes MLN, Borges AS, Peiró JR, Pituco EM, Bonjardim CA, Ferreira PCP, Kroon EG (2003) Araçatuba virus: A vaccinia like virus associated with infection in humans and cattle. Emerg Infect Dis 9(2): 155-160 
19. Tscharke DC, Smith GL (1999) A model for vaccinia virus pathogenesis and immunity based on intradermal injection of mouse ear pinnae. J Gen Virol 80: 2751-2755

20. Turner GS (1967) Respiratory infection of mice with vaccinia virus. J Gen Virol 1: 399-402

Author's address: Dr. Adrian Lewis, Virology Department, National Institute of Infectious Diseases, ANLIS, "Dr. Carlos G. Malbrán”, Av. Velez Sarsfield 563 (1281), Buenos Aires, Argentina; e-mail: alewis@anlis.gov.ar

Verleger: Springer-Verlag GmbH, Sachsenplatz 4-6, 1201 Wien, Austria. - Herausgeber: Dr. M. H. V. Van Regenmortel, École Supérieure de Biotechnologie de Strasbourg (ESBS), Parc d’Innovation, Boulevard Sébastian Brandt, 67400 Illkirch, France. - Redaktion: Sachsenplatz 4-6, 1201 Wien, Austria. - Satz und Umbruch: Thomson Press (India) Ltd., Chennai, India. - Offsetdruck: Holzhausen Druck \& Medien GmbH, Holzhausenplatz 1, 1140 Wien, Austria. - Herstellungsort: Wien, Austria. - Printed in Austria. 